Jurnal Agroteknologi, Vol. 7 No. 2, Februari 2017: 27 - 32

\title{
POTENSI PENGEMBANGAN SORGUM SEBAGAI PANGAN ALTERNATIF, PAKAN TERNAK DAN BIOENERGI DI ACEH
}

\author{
(Potential of Sorghum Development As Alternative Food, Animal Feed And Bio Energy In Aceh)
}

\author{
ELVIRA SARI DEWI DAN MUHAMMAD YUSUF \\ Program Studi Agroekoteknologi \\ Fakultas Pertanian Universitas Malikussaleh \\ Email: elvira@unimal.ac.id
}

\begin{abstract}
This study aims to introduce sorghum and its potential as an alternative food, fodder and also a source of energy in the form of bioethanol. This activity targets the absence of accurate information about the sorghum varieties suitable for all of the end product of sorghum. Adaptability allows sorghum to be planted on marginal lands without having to compete against the land with important agricultural crops. The observed variables including generative morphological traits and yield components and the potential of bioethanol will be produced. The study of variables of the generative traits (plant height, panicle length, and panicle weight) and yield components (weight of 100 seeds / plot and seed dry weight / plot) shows that the three varieties tested responded well to the environment where is growing. Varieties Pahat indicates growth response and the best results followed by Kawali and UPCA. Pahat is more likely to be studied and developed in Aceh.
\end{abstract}

Keywords; Aceh, adaptation, potential ,sorghum

\section{PENDAHULUAN}

Sorgum (Sorghum bicolor L. Moench) merupakan tanaman serealia yang memiliki potensi untuk dibudidayakan baik di daerah kering maupun di daerah dengan curah hujan tinggi. Aceh sebagai salah satu wilayah dengan sumber daya alam yang sangat besar menjadikan wilayah ini sesuai untuk pengembangan sorgum. Bervariasinya tipe agroekosistem yang ada di Aceh tidaklah menjadi persoalan mengingat tanaman ini memiliki daya adaptasi yang luas. Berbagai studi telah menunjukkan ketahanan tanaman ini terhadap kondisi kering ataupun kondisi tergenang. Sorgum juga dapat beradaptasi baik pada daerah dengan jenis tanah yang berbeda-beda ataupun daerah dengan jenis tanah beracun.

Tanaman sorgum telah dikenal dan dibudidayakan sejak lama di beberapa daerah di Indonesia seperti Jawa Tengah, Yogyakarta, Jawa Timur, sebagian wilayah NTB dan NTT (Sirappa, 2003). Di Aceh sendiri, terutama wilayah utara, sorgum dikenal dengan nama "langla" untuk jenis berbatang tinggi sedangkan yang berbatang rendah dikenal dengan sebutan "sorgum". Berdasarkan informasi yang diperoleh dari masyarakat daerah Sawang, Aceh Utara dan sekitarnya, pemanfaatan tanaman ini hanya terbatas sebagai pengalih hama burung pada tanaman padi gunung atau padi ladang. Sementara itu, potensi yang dimiliki sorgum tidak hanya terbatas sebagai pengalih saja. Telah banyak penelitian yang membuktikan bahwa sorgum dapat digunakan sebagai pangan, pakan ternak (Rai et al., 2004) dan penghasil etanol (Smith, 2003).

Biji sorgum merupakan salah satu sumber kalori penting sebagai pangan yang mencapai 332 kalori, jumlah karbohidrat yang mencapai $73,0 \mathrm{~g}$; protein $11,0 \mathrm{~g}$; lemak $3,3 \mathrm{~g}$; kalsium $28 \mathrm{mg}$; fosfor $287 \mathrm{mg}$; zat besi 4,4 mg; vitamin B1 0,38 mg (Depkes RI, 1992 dalam Human Januari 2014). Berdasarkan kandungan nilai gizi yang dimiliki sorgum sudah selayaknya tanaman ini dimanfaatkan secara luas sehingga kebutuhan gizi masyarakat dapat terpenuhi. Namun konsumsi sorgum sebagai pangan pengganti beras di Indonesia masih sangat rendah. Reddy et al. (1995) menyatakan bahwa sorgum tidak hanya dapat dikonsumsi sebagai pangan utama tapi juga dapat digunakan untuk roti, tortila, pop sorgum dan juga makanan ringan. Biji sorgum juga banyak digunakan untuk pakan ternak baik secara langsung maupun sebagai bahan tambahan pembuatan pakan ternak jadi. Selain itu karbohidrat yang dikandung biji juga dapat dikonversi menjadi etanol. Berdasarkan potensi yang dimiliki oleh biji sorgum, 
pengembangannya akan menjadi solusi bagi terhadap krisis pangan.

Perakitan varietas sorgum yang dilakukan oleh Badan Litbang saat ini diarahkan bukan hanya untuk pangan tetapi juga untuk produksi bioetanol. Etanol yang dihasilkan biasanya digunakan sebagai pengganti bahan bakar minyak, farmasi dan substitusi premium. Umumnya etanol yang diperoleh berasal dari nira yang terdapat pada batang terutama pada varietas sorgum manis. Nira yang diperoleh dari batang varietas sorgum manis berpotensi sebagai sumber alternatif bahan baku gula cair. Produksi gula cair ini empat kali lebih murah dibandingkan dari gula tebu.

Sorgum sebagai tanaman dengan peringkat kelima setelah gandum, beras, jagung dan jelai menjadi salah satu komoditi strategis yang membutuhkan penelitian lebih banyak terutama di Indonesia sebagaimana disampaikan oleh Kepala Penelitian dan Pengembangan pada Kementertian Pertanian (Tunggal, November 2012). Penelitian pendahuluan telah dilakukan untuk mendapatkan varietas yang sesuai dikembangkan di Aceh Utara. Sejauh ini hanya melibatkan 5 varietas sorgum hasil rakitan Balai Penelitian Tanaman Serealia di Maros, Sulawesi Selatan. Hasil yang didapat menunjukkan bahwa varietas CTY-33 memiliki berat berangkasan basah tinggi yang berpotensi sebagai bahan hijauan pakan ternak. Varietas yang sama juga menunjukkan berat 100 biji yang tinggi sehingga berpotensi baik bila dimanfaatkan sebagai pangan alternatif kedepannya (Elvira, 2014).

Melihat besarnya potensi yang dimiliki sorgum, Kementerian Pertanian telah menjadikan sorgum sebagai salah satu tanaman yang terus diteliti dan dikembangkan baik teknologi maupun penciptaan varietasvarietas unggul baru. Upaya ini diharapkan mampu mendukung program pemerintah terhadap diversifikasi pangan. Namun program ini lebih diutamakan di wilayah timur Indonesia. Sementara, melihat luasnya lahan tidur yang ada di Aceh terutama Aceh Utara yang mencapai lebih kurang 20.000 hektar dan belum teroptimalisasi dengan baik, menjadikan topik ini sangat layak untuk dikaji secara mendalam. Penelitian ini bertujuan untuk memperkenalkan sorgum dan potensinya sebagai pangan alternatif, pakan ternak dan juga sumber energi berupa bioetanol.

\section{BAHAN DAN METODE}

Penelitian dilaksanakan di Kebun Percobaan Fakultas Pertanian Universitas Malikussaleh, Aceh Utara dari bulan Maret sampai dengan Agustus 2016. Beberapa varietas yang diteliti diantaranya adalah Kawali, Pahat dan UPCA. Penelitian ini menggunakan pupuk dasar berupa pupuk kandang, Urea, TSP dan KCl. Susunan penelitian mengikuti Rancangan Acak Kelompok non faktorial terdiri dari tiga varietas yaitu Kawali (V1), Pahat (V2), dan UPCA (V3). Masing-masing perlakuan terdiri dari 6 tanaman sampel yang diamati untuk tinggi tanaman, panjang malai, berat malai, berat berangkasan basah, berat 100 biji per varietas, berat biji per plot, kandungan nira dalam $1 \mathrm{~kg}$ batang dan kadar gula brix nira.

Pelaksanaan penelitian dimulai dengan menyiapkan lahan dan dibuat bedengan berukuran 2,5 $\mathrm{m} \times 1 \mathrm{~m}$. Jarak antar bedengan $50 \mathrm{~cm}$ sedangkan jarak antar ulangan $1 \mathrm{~m}$. Tiga varietas ditanam menggunakan jarak tanam $40 \mathrm{~cm} \times 20 \mathrm{~cm}$. Kegiatan pemeliharaan tanaman meliputi tahapan penyiraman, pemupukan, penjarangan, penyulaman, dan pengendalian hama serta penyakit. Sorgum dipanen secara bertahap dimulai dari 120 hari setelah tanam. Pemanenan dilakukan setelah tanaman menunjukkan ciri-ciri matang secara visual seperti daun menguning dan kering, biji bernas dan keras serta berkadar tepung tinggi. cara panen dengan memotong pangkal tangkai atau malai sampai batang leher malai.

HASIL

\section{HASIL DAN PEMBAHASAN}

Pertambahan tinggi tanaman sorgum pada pengamatan hari 7 - 14 HST, $14-28$ HST, 28 - 42 HST, 42 - 56 HST, dan 56 - 70 HST dapat di lihat pada Gambar 1. Ketiga varietas yang dicobakan menunjukkan pola perkembangan pertumbuhan yang hampir sama, kecuali pada varietas Kawali yang menunjukkan pertambahan tinggi tanaman yang menonjol di akhir fase pertumbuhan.

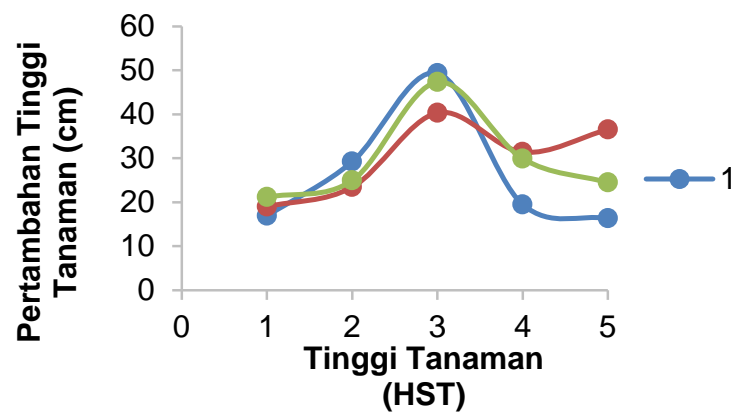

Gambar 1. Pertambahan tinggi tanaman sorgum

Pertambahan jumlah daun tanaman sorgum pada pengamatan 14 - 28 HST, 28 - 
42 HST, 42 - 56 HST, dan 56 - 70 HST dapat di lihat pada Gambar 2. Gambar menunjukkan adanya pola perkembangan yang berbeda dari ketiga varietas yang dicobakan. Varietas Pahat dan Kawali menunjukkan pertambahan jumlah daun yang terus meningkat sampai pada fase pertumbuhan akhir, sedangkan untuk varietas UPCA tidak terdapat pertambahan jumlah daun di akhir fase pertumbuhan akhir tanaman.

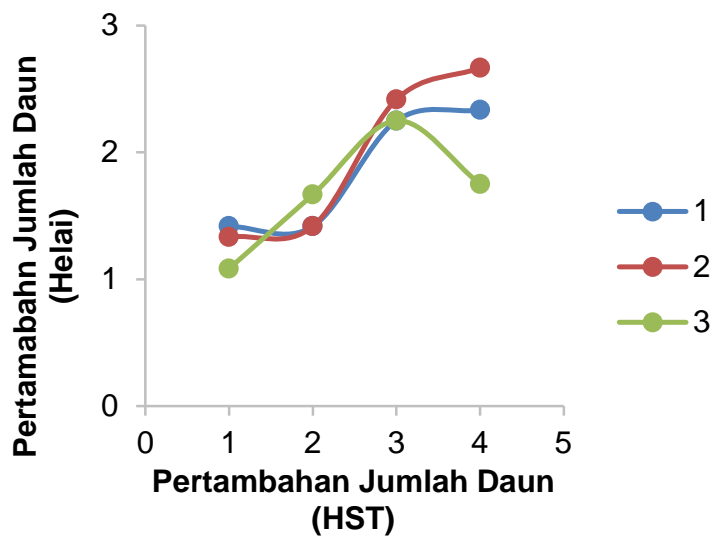

Gambar 2. Pertambahan jumlah daun tanaman sorgum

Pertambahan diameter batang tanaman sorgum pada 28 - 42 HST, $42-56$ HST, dan 56 - 70 HST dapat di lihat pada Gambar 3. Gambar 3 menunjukkan bahwa adanya perbedaan yang tidak signifikan pada pola perkembangan batang tanaman. Ketiga varietas yang dicobakan menunjukkan pertambahan yang signifikan pada fase awal pertumbuhan dan terus menurun pada pertengahan sampai tanaman berada pada fase akhir pertumbuhan vegetatif.

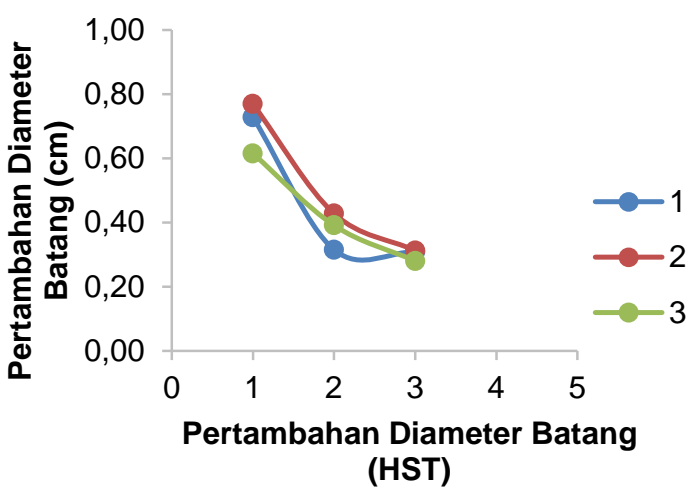

\section{Gambar 3. Pertambahan diameter batang tanaman sorgum}

Rata-rata panjang malai, berat malai basah, berat biji per plot, dan berat 100 biji per tanaman dapat di lihat pada Tabel 1. Data tabel menunjukkan bahwa varietas Pahat memiliki malai terpanjang, berat malai basah tertinggi, berat biji per plot dan berat 100 biji per tanaman tertinggi. Selanjutnya diikuti oleh varietas Kawali dan UPCA.

Tabel 1. Rata-rata panjang malai, berat malai basah, berat biji per plot, dan berat 100 biji per tanaman sorgum.

\begin{tabular}{ccccc}
\hline Varietas & $\begin{array}{c}\text { Panjang } \\
\text { malai } \\
(\mathrm{cm})\end{array}$ & $\begin{array}{c}\text { Berat } \\
\text { malai } \\
\text { basah } \\
(\mathrm{g})\end{array}$ & $\begin{array}{c}\text { Berat } \\
\text { biji per } \\
\text { plot }(\mathrm{g})\end{array}$ & $\begin{array}{c}\text { Berat } \\
100 \text { biji } \\
\text { per } \\
\text { tanaman } \\
(\mathrm{g})\end{array}$ \\
\hline Pahat & 30,92 & 372,53 & 643,33 & 2,84 \\
Kawali & 19,33 & 334,47 & 610,00 & 2,16 \\
UPCA & 11,17 & 145,70 & 253,33 & 1,06 \\
\hline
\end{tabular}

\section{PEMBAHASAN}

Pertambahan tinggi tanaman sorgum pada pengamatan hari $7-14 \mathrm{HST}, 14-28$ HST, 28 - 42 HST, 42 - 56 HST dan 56 - 70 HST dapat di lihat pada Gambar 1. Ketiga varietas yang dicobakan menunjukkan pola perkembangan pertumbuhan yang hampir sama, kecuali pada varietas Kawali yang menunjukkan pertambahan tinggi tanaman yang menonjol di akhir fase pertumbuhan. Hal ini disebabkan oleh pengalihan energi dari fase vegetatif ke fase generatif menjelang masuknya masa berbunga sehingga tanaman tidak lagi tumbuh secara vertikal namun lebih pada perkembangan bunga dan pengisian biji sorgum. Tinggi tanaman merupakan indikator penting bagi biomassa yang dihasilkan terutama bagi perkembangan varietas multi fungsi atau berpotensi sebagai bioenergi (Fernandez, et al., 2009).

Pada parameter pertambahan jumlah daun, varietas Pahat dan Kawali masih menunjukkan adanya pertambahan jumlah daun di waktu menjelang fase perkembangan generatif, namun jumlah tersebut tidaklah signifikan, begitu pula pada varietas UPCA (Gambar 2.). Perbedaan perkembangan daun seperti ukuran kanopi yang lebih kecil, vigor tanaman yang tertunda, atau peningkatan laju tampilan daun diyakini dapat meningkatkan hasil gabah terutama dalam kondisi kering (Kholová, et al., 2014).

Pola perkembangan yang sama juga ditunjukkan oleh diameter batang pada setiap waktu pengamatan. Baik varietas Pahat, Kawali maupun UPCA menunjukkan laju pertumbuhan yang cepat di fase pertumbuhan awal. Namun, laju pertumbuhan terus menurun sejalan dengan pertumbuhan dan perkembangan tanaman ke arah generatif. Hal ini sesuai dengan pendapat Balole (2001) yang menyatakan bahwa setelah pembungaan, 
asimilat yang dihasilkan akan dibatasi penggunaannya untuk pertumbuhan daun, batang, dan akar tanaman.

Pengalihan energi dari fase vegetatif ke fase generatif mengakibatkan perkembangan faktor generatif yang baik seperti panjang malai, berat malai basah, berat biji per plot dan berat 100 biji per tanaman. Varietas Pahat menunjukkan parameter yang paling menonjol untuk semua variabel tersebut secara berurut yakni $30,92 \mathrm{~cm} ; 372,53 \mathrm{~g}$; 643,33 ; dan 2,84 g dibandingkan dengan varietas lainnya. Respon paling rendah ditunjukkan oleh varietas UPCA, secara berurut yaitu $11,17 \mathrm{~cm} ; 145,70 \mathrm{~g} ; 253,33 \mathrm{~g}$; dan $1,06 \mathrm{~g}$.

Perbedaan hasil dari setiap parameter yang diamati disebabkan oleh perbedaan susunan genetis dari setiap varietas yang digunakan. Hal serupa ditunjukkan oleh Bhoya et al. (2013) yang menemukan bahwa setiap varietas memberikan respon berbeda terhadap variabel amatan baik disebabkan oleh faktor genetik maupun faktor lingkungan. Adaptasi terhadap kondisi tumbuh yang berbeda menyebabkan berbedanya respon tumbuh sorgum yang ditunjukkan oleh berbedanya tinggi, diamater, jumlah daun dan faktor hasil (Regassa dan Wortmann, 2014). Dengan demikian, penggunaan varietas yang telah diperbaiki baik seperti Pahat, Kawali ataupun UPCA sangat dimungkinkan untuk digunakan sebagai sumber energi berkelanjutan (Mullet et al., 2014).

\section{SIMPULAN}

Varietas Pahat menunjukkan respon pertumbuhan dan hasil yang paling baik diikuti oleh varietas Kawali dan UPCA. Varietas Pahat lebih berpeluang untuk dikaji dan dikembangkan di Aceh.

\section{UCAPAN TERIMA KASIH}

Penelitian ini terlaksana atas pendanaan oleh Direktorat Riset dan Pengabdian Masyarakat, Direktorat Jenderal Penguatan Riset dan Pengembangan Kementerian Riset, Teknologi, dan Pendidikan Tinggi sesuai dengan Surat Perjanjian Penugasan Pelaksanaan Program Penelitian Nomor: 060/SP2H/LT/DPRM/II/2016, tanggal 17 Februari 2016.

\section{DAFTAR PUSTAKA}

Balole, T. V. 2001. Strategies to improve yield and quality of sweet sorghum as a cash crop for small scale farmers in
Botswana (Doctoral dissertation, University of Pretoria Pretoria).

Elvira, S. D. 2014. Hasil beberapa varietas sorgum pada lahan marginal di Aceh Utara. Prosiding.

Fernandez, M. G. S., Becraft, P. W., Yin, Y., \& Lübberstedt, T. 2009. From dwarves to giants? Plant height manipulation for biomass yield. Trends in plant science, 14(8), 454-461.

Human, S. 2007. Riset \& Pengembangan Sorgum dan Gandum Untuk Ketahanan Pangan. Makalah. Pusat Aplikasi Teknologi Isotop dan Radiasi, Badan Tenaga Nuklir Nasional (BATAN), Jakarta Selatan.

Kholová, J., Murugesan, T., Kaliamoorthy, S., Malayee, S., Baddam, R., Hammer, G. L., and Vadez, V. 2014. Modelling the effect of plant water use traits on yield and stay-green expression in sorghum. Functional Plant Biology, 41(11), 1019-1034.

Mullet, J., Morishige, D., McCormick, R., Truong, S., Hilley, J., McKinley, B., and Rooney, W. 2014. Energy Sorghum-a genetic model for the design of $\mathrm{C} 4$ grass bioenergy crops. Journal of experimental botany, 229.

Rai, K. N., Reddy, B. V. S., Saxena, K. B., \& Gowda, C. L. L. 2004. Prospects of breeding sorghum, pearl millet and pigeonpea for high forage yield and quality.

Reddy, B. V. S., Stenhouse, J. W., \& Rattunde, H. F. W. 1995. Sorghum Grain Quality Improvement for Food, Feed and Industrial Uses. Edisi Khusus Balai Penelitian Tanaman Kacang-kacangan dan Umbi-umbian, (4-1995), 39-52.

Regassa, T. H., \& Wortmann, C. S. 2014. Sweet sorghum as a bioenergy crop: literature review. Biomass and Bioenergy, 64, 348-355.

Sirappa, M. P. 2003. Prospek pengembangan sorgum di Indonesia sebagai komoditas alternatif untuk pangan, pakan, dan industri. Jurnal Litbang Pertanian, 22(4), $133-140$

Smith, R. 2013. Prospect promising for grain sorghum. Southwest Farm Press. (http://southwestfarmpress.com/prospect 
Jurnal Agroteknologi, Vol. 7 No. 2, Februari 2017: 27 - 32

s-promising-grain-sorghum). Diakses pada tanggal 7 Oktober 2013.

Tunggal, N. 2012. 100 varietas sorgum jepang diuji coba di cibinong. Kompas.com. (http://internasional.kompas.com/read/2 012/11/21/17402059/100.Varietas. Sorgu m.Jepang.Diuji.Coba.di.Cibinong?utm s ource=RD\&utm medium=box\&utm cam paign=Kaitrd). Diakses pada tanggal 21 Nopember 2012. 
Potensi Pengembangan Sorgum Sebagai Pangan Alternatif (Dewi dan Yusuf) 